\title{
Assessment of the Knowledge and Attitude on HIV/AIDS Among Drivers' Wives
}

\author{
Prajapati LM, ${ }^{1}$ Sanjel $S,{ }^{2}$ Khanal K ${ }^{2}$
}

${ }^{1}$ Department of Nursing

${ }^{2}$ Department of Community Medicine

Dhulikhel Hospital,kathmandu University Hospital Kathmandu University Medical School, Dhulikhel Kavre, Nepal

\section{Corresponding Author}

Laxmi Maiya Prajapati (Awa)

Kathmandu University School of Medical Sciences

Dhulikhel Hospital- Kathmandu University Hospital

Dhulikhel, Kavre, Nepal

Email: Impawa@yahoo.com

\section{Citation}

Prajapati LM, Sanjel S, Khanal K. Assessment of the knowledge and Attitude on HIV/AIDS among Drivers' Wives. Kathmandu Univ Med J 2012;10(4):20-24.

\section{ABSTRACT \\ Backgroud}

It is generally accepted and well-documented that long distance drivers remain one of the key forces in the spread of HIV/AIDS as they are highly mobile and spending long hours on the road away from their families which makes them very likely to use the services of commercial sex workers (CSWs).

\section{Objectives}

To identify the knowledge and attitude among Drivers' wives on HIV/AIDS.

\section{Methods}

A cross-sectional survey was conducted between August and September 2010 to assess the knowledge and attitude of drivers' wives on HIV/AIDS in Banepa, Dhulikhel and Panuti Municipalities, Kavre district central Nepal. Using social network sampling technique 248 drivers' wives were selected. Data were obtained using the structured and semi-structured questionnaire through interview technique. Verbal consent was taken before collecting data. Both descriptive and inferential statistics were computed.

\section{Results}

Ninety six percent of the respondents heard of HIV/ AIDS. Majority (65.7\%) of the sources of the information were television followed by radio (56.5\%), friends (33.5\%), husband (19.4\%), newspapers (17.7\%) and posters (17.3\%). The educational status and economic status of the respondents show significant association. The parameters regarding attitude revealed statistical significant.

\section{Conclusion}

The age and ethnicity of the respondents did not exhibit the association with awareness on HIV/ AIDS whereas, educational status and economic status of the respondents and the parameters regarding attitude revealed statistical show significant association.

\section{KEY WORD}

AIDS, attitude, drivers' wives, HIV, knowledge 


\section{INTRODUCTION}

It is generally accepted and well-documented that long distance drivers remain one of the key forces in the spread of HIV/AIDS as they are highly mobile and spending long hours on the road away from their families which makes them very likely to use the services of commercial sex workers (CSWs) in stop-over near major transportation routes. ${ }^{1}$ The most common types of clients for the CSWs were drivers. ${ }^{2}$ Although $96 \%$ of drivers have heard of AIDS, their knowledge of HIV transmission, risks and available preventive measures were quite low. ${ }^{3}$ The drivers visiting sex workers at stop found an overall HIV prevalence of $56 \%$; drivers as a group are highly sexually active for example $37 \%$ drivers visiting CSWs at stop stopped for sex with them, $42 \%$ practiced anal sex, $<25 \%$ used condoms during anal sex, $29 \%$ never used condoms with CSWs, and $13 \%$ used condoms with their wives. ${ }^{4,5}$

The CSWs perform sex in exchange for gifts or money and drivers believe that a personal relationship of sorts exists between them and they will be less likely to use a condom during sexual relations as their perception of low risks. ${ }^{6}$ The resulting co-mingling of the two mobile, sexually active, high-risk populations elucidates high prevalence of HIV and STI rates in drivers and the subsequent spread of the disease to their wives. ${ }^{1,7}$

Women's lack of access to education or personal income perpetuate women's lower status and create even greater vulnerability to HIV infection. ${ }^{8}$ Therefore, this study was conducted to identify the knowledge and attitude among Drivers' wives on HIV/AIDS.

\section{METHODS}

A cross-sectional survey was conducted between August and September 2010 to assess the knowledge and attitude of Drivers' wives on HIV/AIDS. The area of study was Banepa, Dhulikhel and Panuti Municipalities, Kavre district of central Nepal. The target population of the study was the Drivers' wives of reproductive age group residing Banepa, Dhulikhel and Panuti Municipalities, Kavre district.

Two hundred and forty eight reproductive age group drivers' wives were selected using social network sampling technique. ${ }^{9}$ The investigator initially provided training for all data enumerator and explained the objectives of the study for filling the questionnaire completely. The questionnaires were filled and edited for accurate, complete and errors free. The questionnaire having three sections: sociodemographic information, knowledge on HIV/ AIDS and attitude on HIV/ AIDS was used. Some questions had multiple responses from which each respondent was asked to select the most appropriate one. The questionnaire was prepared after an extensive literature search. The content validity of the questionnaire was obtained through the review of other questionnaires used in Nepal and abroad and by discussions with experts during the preparatory phase of questionnaire development. The construct validity of some of these content areas has been reported previously.

Data were collected using interview method by data collectors after having data collection training and involving for pre-testing of Nepali version questionnaire and subsequent revision. ${ }^{10,11}$ Permission from institutional review committee (IRC) of the Kathmandu University School of Medical Sciences (KUSMS) and Nepal Transport Employees Organization (Yatayat Majdur Sangh) was taken before implementing the survey. Verbal consent for each respondent was taken before collecting data.

Data were edited at the same evening of the data collection by cross-checking from different interviewers. After categorization and entry, analysis was done in SPSS software version 16. Both descriptive (mean, standard deviation and proportion) and inferential $(\chi 2)$ statistics were computed.

\section{RESULTS}

Age, ethnicity, religion, educational status and economic status of the respondents were measured. The respondents were of mean age $29.55 \pm 8.21$ years with minimum of 18 years and the maximum of 59 years (table 1 ).

Table 1. Socio-demographic findings.

\begin{tabular}{lcc|}
\hline Age in groups & Frequency & Percent \\
\hline$\leq 20$ years & 29 & 11.7 \\
\hline 21- 30 years & 132 & 53.2 \\
\hline 31 - 40 years & 65 & 26.2 \\
\hline$\geq 41$ years & 22 & 8.9 \\
\hline Total & 248 & 100.0 \\
\hline Ethnicity of the respondents & & \\
\hline Brahmin/ Chhetri & 118 & 47.6 \\
\hline Newar & 53 & 21.4 \\
\hline Tamang/ Magar & 58 & 23.4 \\
\hline Ethnic minority groups & 19 & 7.7 \\
\hline Total & 248 & 100.0 \\
\hline Religion of the respondents & & \\
\hline Hindu & 227 & 9135 \\
\hline Buddhist & 18 & 7.3 \\
\hline Christian & 24.5 & 100.0 \\
\hline Total & 248 & \\
\hline Educational status & & 100.0 \\
\hline Illiterate & 83 & \\
\hline Literate & & \\
\hline Total & & \\
\hline & & \\
\hline
\end{tabular}

Ninety six percent of the respondents heard of HIV/ AIDS. For majority (65.7\%), the sources of the information were television (Fig. 1). About 17 to $47 \%$ of the respondents were familiar with the symptoms of AIDS. Knowledge on 


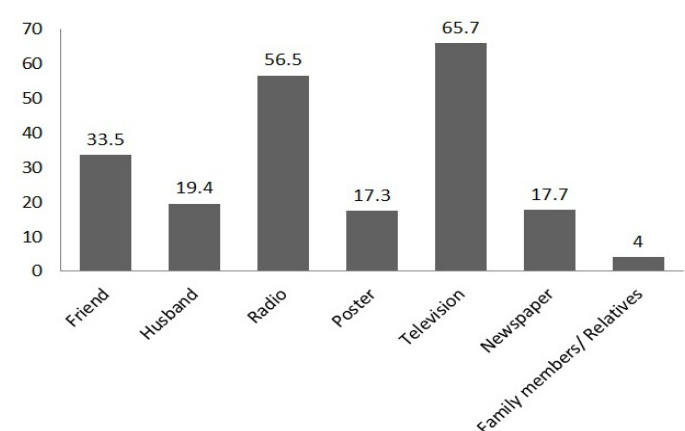

Figure 1. The sources of information on HIV/AIDS (\%).

Table 2. Knowledge on HIV/ AIDS.

\begin{tabular}{|lcl|}
\hline Symptoms of Symptoms of AIDS & Frequency & Percent \\
\hline $\begin{array}{l}\text { Chronic Diarrhea for more than 1 } \\
\text { month }\end{array}$ & 78 & 31.5 \\
\hline $\begin{array}{l}\text { Loss of body weight } \\
\text { Long term fever and common cold }\end{array}$ & 117 & 47.2 \\
\hline Vesicles or warts around mouth & 93 & 37.5 \\
\hline Rashes in the skin & 39 & 15.7 \\
\hline $\begin{array}{l}\text { Transmission of HIV/ AIDS } \\
\text { Through sexual intercourse }\end{array}$ & 43 & 17.3 \\
\hline $\begin{array}{l}\text { From affected mother to baby } \\
\text { From affected person's blood }\end{array}$ & 152 & 61.3 \\
\hline From infected needles & 127 & 50.2 \\
\hline $\begin{array}{l}\text { Person's with multiple sexual } \\
\text { partners }\end{array}$ & 124 & 50.0 \\
\hline $\begin{array}{l}\text { Baby delivered from the affected } \\
\text { mother }\end{array}$ & 103 & 41.5 \\
\hline $\begin{array}{l}\text { From needle users among drug } \\
\text { addicts }\end{array}$ & 159 & 64.1 \\
\hline $\begin{array}{l}\text { Through sexual intercourse } \\
\text { Modes of prevention of HIV/ AIDS }\end{array}$ & 102 & 37.9 \\
\hline $\begin{array}{l}\text { Early treatment of STDs } \\
\text { Use of sterilized needle }\end{array}$ & 87.9 \\
\hline
\end{tabular}

transmission of HIV/ AIDS was from about 41 to 82 percent and the knowledge on the mode of transmission of STIs and HIV/ AIDS from about 27 to 53 percent (table 2).

To access the attitudes on HIV/ AIDS and behavior, a five scale raring scale from strongly agree, agree, neutral, disagree and strongly disagree with weight from 5 to 1 was implemented. There were questions including HIV/AIDS is caused due to the curse of God $(4.40 \pm 0.82)$, support is required for people affected with HIV/AIDS (4.33 \pm 0.77$)$, affected person should be isolated $(4.10 \pm 0.86)$, husband and wife should talk openly about HIV/AIDs (4.24 \pm 0.75$)$, should tell it to other people if one of your family member is affected from HIV/AIDS $(4.13 \pm 0.81)$, if any employee is suffering from HIV/AIDS then he/she should be fired from the job $(4.35 \pm 0.93)$, a child with HIV/AIDS should
Table 3. Attitude and behavior on HIV/ AIDS ( $\mathbf{n}=\mathbf{2 4 8}$ ).

\begin{tabular}{|c|c|c|}
\hline Practice on HIV/ AIDS & Mean \pm SD & $P$ value \\
\hline $\begin{array}{l}\text { HIV/AIDS is caused due to the } \\
\text { curse of God }\end{array}$ & $4.40 \pm 0.82$ & $0.000 * *$ \\
\hline $\begin{array}{l}\text { Support is required for people } \\
\text { affected with HIV/AIDS }\end{array}$ & $4.33 \pm 0.77$ & $0.000 * *$ \\
\hline $\begin{array}{l}\text { Affected person should be } \\
\text { isolated }\end{array}$ & $4.10 \pm 0.86$ & $0.001 * *$ \\
\hline $\begin{array}{l}\text { Husband and wife should talk } \\
\text { openly about HIV/AIDs }\end{array}$ & $4.24 \pm 0.75$ & $0.000 * *$ \\
\hline $\begin{array}{l}\text { Should tell other people if } \\
\text { one of your family member is } \\
\text { affected from HIV/AIDS }\end{array}$ & $4.13 \pm 0.81$ & $0.030 * *$ \\
\hline $\begin{array}{l}\text { If any employee is suffering } \\
\text { from HIV/AIDS then he/she } \\
\text { should be fired from the job }\end{array}$ & $4.35 \pm 0.93$ & $0.000 * *$ \\
\hline $\begin{array}{l}\text { A child with HIV/AIDS should } \\
\text { be abandoned from school/ } \\
\text { college }\end{array}$ & $4.23 \pm 1.01$ & $0.000 * *$ \\
\hline $\begin{array}{l}\text { Affected person should get } \\
\text { treatment }\end{array}$ & $4.15 \pm 0.95$ & $0.000 * *$ \\
\hline $\begin{array}{l}\text { One should not be involved } \\
\text { in community programmes of } \\
\text { affected with HIV/AIDS }\end{array}$ & $3.96 \pm 0.06$ & $0.000 * *$ \\
\hline $\begin{array}{l}\text { HIV/AIDS is only transmitted to } \\
\text { people having unsafe sex. }\end{array}$ & $3.30 \pm 1.06$ & $0.002 * *$ \\
\hline $\begin{array}{l}\text { Person who looks healthy is } \\
\text { not affected by HIV/AIDS }\end{array}$ & $3.60 \pm 1.03$ & $0.333^{* *}$ \\
\hline $\begin{array}{l}\text { Hating people affected with } \\
\text { HIV/AIDS should be stopped }\end{array}$ & $4.25 \pm 1.00$ & $0.000^{* *}$ \\
\hline $\begin{array}{l}\text { People suffered with HIV/AIDS } \\
\text { should be treated well. }\end{array}$ & $4.46 \pm 0.73$ & $0.000 * *$ \\
\hline
\end{tabular}

be abandoned from school/college (4.23 \pm 1.01$)$, affected person should get treatment $(4.15 \pm 0.95)$, one should not be involved in community programmes if affected with HIV/AIDS $(3.96 \pm 0.06)$, HIV/AIDS is only transmitted to people having unsafe sex $(3.30 \pm 1.06)$, person who looks healthy is not affected by HIV/AIDS (3.60 \pm 1.03 ), hating people affected with HIV/AIDS should be stopped (4.25 \pm 1.00$)$, people suffered with HIV/AIDS should be treated respectively $(4.46 \pm 0.73)$ (table 3$)$.

The association between awareness on HIV/ AIDS and different variable were assessed. The age and ethnicity of the respondents did not exhibit the association with awareness on HIV/ AIDS whereas, educational status and economic status of the respondents show significant association on the awareness at $5 \%$ level of significant (table 4).

\section{DISCUSSION}

This study was conducted to assess the knowledge and attitude on HIV/AIDS among drivers' wives. a high literacy rate, the proactive mass media, the emphasis on health renders the awareness on this sensitive issue. ${ }^{12}$ Among 248 respondents, $94 \%$ heard of HIV/ AIDS which was similar 
Table 4. Association among awareness on HIV/ AIDS and other variables.

\begin{tabular}{|c|c|c|c|}
\hline \multirow[t]{2}{*}{ Age groups } & \multicolumn{2}{|c|}{ Awareness on HIV/AIDS } & \multirow{2}{*}{$\begin{array}{l}\text { P value } \\
\text { in } \chi 2 \text { test }\end{array}$} \\
\hline & Yes & No & \\
\hline$<20$ years & $29(100)$ & 0 & \multirow{5}{*}{0.113} \\
\hline $21-30$ years & $129(97.7)$ & $3(2.3)$ & \\
\hline 31 - 40 years & $60(92.3)$ & $5(7.7)$ & \\
\hline$>41$ years & 20 (90.9) & $2(9.1)$ & \\
\hline Total & $238(96.0)$ & $10(4.0)$ & \\
\hline \multicolumn{4}{|l|}{ Ethnicity } \\
\hline $\begin{array}{l}\text { Brahmin/ } \\
\text { Chhetry }\end{array}$ & $115(97.5)$ & $3(2.5)$ & \multirow{5}{*}{0.209} \\
\hline Newar & $52(98.1)$ & $1(1.9)$ & \\
\hline $\begin{array}{l}\text { Taqmang/ } \\
\text { Magar }\end{array}$ & $53(91.4)$ & $5(8.6)$ & \\
\hline $\begin{array}{l}\text { Ethnic and } \\
\text { minority }\end{array}$ & $18(94.7)$ & $1(5.3)$ & \\
\hline Total & $238(96.0)$ & $10(4.0)$ & \\
\hline \multicolumn{4}{|c|}{ Educational status } \\
\hline Illiterate & $74(89.2)$ & $9(10.8)$ & \multirow{3}{*}{0.000} \\
\hline Literate & $164(99.4)$ & $1(0.6)$ & \\
\hline Total & $238(96.0)$ & $10(4.0)$ & \\
\hline \multicolumn{4}{|c|}{ Economic Status } \\
\hline Adjustable & $226(96.6)$ & $8(3.4)$ & \multirow{3}{*}{0.045} \\
\hline Insufficient & $12(85.7)$ & $2(14.3)$ & \\
\hline Total & $238(96.0)$ & $10(4.0)$ & \\
\hline
\end{tabular}

(96\%) to the study done in Burkina Faso. ${ }^{13}$ Concerning the symptoms of HIV/ AIDS, $47.2 \%$ answered the loss of body weight, $37.5 \%$ responded long term fever and common cold, $31.5 \%$ thought chronic diarrhea for more than a month, $17.3 \%$ supposed rashes in the skin and $15.7 \%$ assumed vesicles and warts around mouth which was lower than a study done in India in which common symptoms of disease was answered by $80.1 \%$ of the respondents. ${ }^{14}$ The association between awareness on HIV/ AIDS and different variable were assessed by $\chi^{2}$ test. The age and ethnicity of the respondents did not exhibit the association with awareness on HIV/ AIDS whereas, educational status and economic status of the respondents show significant association at $5 \%$ level of significant.

In relation to the knowledge on the transmission of HIV/ AIDS, $81.9 \%$ reflected sexual intercourse, $64.1 \%$ signaled person's with multiple sexual partners, $51.2 \%$ indicated from affected mother to baby, 50.0\% affected person's blood, $41.5 \%$ infected needles, $41.1 \%$ baby delivered from affected mother and $35.1 \%$ needle users among drug addicts that was similar to the study done in India where $82.78 \%$ of respondents responded that the sexual intercourse in the most common mode of transmission of HIV/ AIDS and a bit different from. ${ }^{14}$ By contrast a study done in Ethiopia revealed that the perception of the mode of transmission were sexual intercourse $98.7 \%$, using unsterile needles and blades $34.1 \%$, blood transfusion $11.7 \%$, breathing $1.6 \%$ and eating together $0.6 \%{ }^{15}$

Regarding the mode of prevention of HIV/ AIDS, $53.2 \%$ answered as having single sexual partner, $41.5 \%$ said use of condoms during sexual intercourse, $37.9 \%$ responded early treatment of STDs and $27.0 \%$ thought use of sterile needle which was similar to findings condom protects HIV/ AIDS $69.5 \%$, AIDS is not treatable $66.0 \%$, STD is treatable $78.1 \%$ and $45.9 \%$ respectively. ${ }^{1,12,13,16}$

To appraise the attitudes on HIV/ AIDS and behavior, a five scale raring scale from strongly agree, agree, neutral, disagree and strongly disagree with weight from five to one was implemented. The mean score was $4.11 \pm 0.538$ ranging from two to five with total mean score of 53.5. The questions; HIV/AIDS is caused due to the curse of God, support is required for people affected with HIV/ AIDS, affected person should be isolated, husband and wife should talk openly about HIV/AIDs, you should tell it to other people if one of your family member is affected from HIV/AIDS, if any employee is suffering from HIV/AIDS then he/she should be fired from the job, a child with HIV/ AIDS should be abandoned from school/college, affected person should get treatment, one should not be involved in community programmes if affected with HIV/AIDS, HIV/AIDS is only transmitted to people having unsafe sex, hating people affected with HIV/AIDS should be stopped and people suffered with HIV/AIDS should be treated were statistically significant at $<0.01$ level of confidence.

\section{CONCLUSION}

The awareness on HIV/ AIDS for the vulnerable groups should be pursued. The age and ethnicity of the respondents did not exhibit the association with awareness on HIV/ AIDS whereas, educational status and economic status of the respondents show significant association at 0,05 level of confidence. The parameters regarding attitude revealed statistical significant at $<0.01$ level of confidence.

\section{ACKNOWLEDGEMENTS}

Our great gratitude goes to the respondents who made this study possible. We would like to thank Nepal Transport Organization (Nepal Yatayat Sangh) for providing immense help during data collection. Our indebted appreciation goes to the research assistants for collecting data in this sensitive issue. 


\section{REFERENCES}

1. Hudson CP. AIDS in rural Africa: a paradigm for HIV-1 prevention. International Journal of Sexually Transmitted Diseases and AIDS July 1996;7(4):236-43.

2. NCASC F. HIV Behavioral Surveillance of Female Sex Workers and their Clients in Kathmandu Valley. July - August 2001.

3. Meda N, Sangare L, Lankoande S, Compaore IP, Catraye J, Sanou PT et.al. [The HIV epidemic in Burkina Faso: current status and the knowledge level of the population about AIDS, 1994-1995 - in French]. Revue Epidemiologie Sante Publique 1998;46(1):14-23.

4. Ramjee G, Karim SS, Sturm AW. Sexually transmitted infections among sex workers in KwaZulu-Natal, South Africa. Sexually Transmitted Diseases Aug 1998;25(7):346-9.

5. Ramjee G, Gouws E. Ramjee G, Gouws E . 2002. Prevalence of HIV among truck drivers visiting sex workers in KwaZulu-Natal, South Africa. Sexually Transmitted Diseases Jan 2002;29(1):44-9.

6. Nnoli C. Motor-park people shift gear. WorldAIDS 1992(19):10.

7. Gysels M, Pool R, Bwanika K. Truck drivers, middlemen and commercial sex workers: AIDS and the mediation of sex in south west Uganda. AIDS Care June 2001;13(3):373-85.

8. Afriyie PA. Women, Poverty and HIV/AIDS in the Abura-AsebuKwamankese District. Oslo: Norwegian University of Science and Technology; 2006.
9. Atkinson R, Flint J. Accessing Hidden and Hard-to-Reach Populations: Snowball Research Strategies; University of Surrey. social research UPDATE. 2001;33.

10. Thabane L, Ma J, Chu R, Cheng J, Ismaila A, P Rios L et.al. A tutorial on pilot studies: the what, why and how. BMC Medical Research Methodology 2010;10(1).

11. Van Teijlingen ER, Hundley V. The importance of pilot studies. social research UPDATE; University of Surrey. 2001(35).

12. Lal SS, Vasan RS, Sarma PS, Thankappan KR. Knowledge and attitude of college students in Kerala towards HIV/AIDS, sexually transmitted diseases and sexuality. Natl Med J India 2000;13(3):231-6.

13. Annonimys. HIV/AIDS Intervention in Truck Drivers Population in Southern Africa: A Review of Literature and BCC Materials 2004.

14. Singh SK, Saxena A, Krishna G. A profile of HIV infection / AIDS related knowledge among female students of Kanpur district, India. Kathmandu Univ Med J 2007;5(17):27-31.

15. Alene GD. Knowledge and practice of condom in preventing HIV/ AIDS infection among commercial sex workers in three small towns of northwestern Ethiopia. EthiopJHealth Dev 2002;16(3):277-286.

16. Niraula SR, Jha N, Mishra RN, Singh SP. Awareness and Risk Taking Behaviours Regarding Sexually Transmitted Diseases among Long Distance Drivers in a Township of Dharan: A Study from Nepal. Indian J Prev Soc Med 2003;34(3 \& 4):130-8. 